\title{
STRATEGI PENGEMBANGAN PROGRAM PEMBELAJARAN PENDIDIKAN AGAMA ISLAM SEKOLAH
}

Diana Susilawati Sj ${ }^{1}$, Muhammad Anas Ma`arif ${ }^{2,}$ Afif Zamroni',

Institut Pesantren Kh. Abdul Chalim Pacet Mojokerto, Indonesia,1,2

Email:nengdianasusilawati94@gmail.com

\begin{tabular}{l}
\hline \\
\hline Keywords: \\
Islamic Religious \\
Education (IRE), \\
Learning \\
Programm, \\
Learning \\
Management \\
\hline
\end{tabular}

Kata Kunci:

Pendidikan Agama

Islam (PAI),

Program

Pembelajaran,

Manajemen

Pembelajaran

\begin{abstract}
The research objective is to describe the process of planning, implementing and controlling the development of Islamic religious education learning programs. The type of research used is qualitative with a case study approach. Data collection techniques using interviews, observation and documentation. informants who are the source of information are the principal, vice principal, curriculum assistant, religion teacher and extracurricular coaches. The results of the research are: 1) planning for the development of Islamic religious education learning programs can be seen in the form of learning tools or programs which include syllabus development, annual plans, semester programs and teaching preparation in the form of learning implementation plans which are based on a study of competency standards, basic competencies and indicators. which is determined based on content standards, competency standards for graduates of Islamic religious education subjects. 2) Implementation of developing learning programs, namely carrying out learning program development activities, following the applicable procedures in schools, namely by organizing and directing the development of learning programs with reference to intracurricular and extracurricular learning. This study also found that controlling the implementation of the learning program was carried out by evaluating student learning outcomes and monitoring class in intracurricular and extracurricular learning.

\begin{tabular}{l} 
Abstrak \\
\hline Tujuan penelitian adalah untuk mendeskripsikan proses \\
perencanaan, pelaksanaan dan pengendalian pengembangan \\
program pembelajaran pendidikan agama Islam. Jenis \\
penelitian yang digunakan adalah kualitatif dengan \\
pendekatan studi kasus. Tehnik pengumpulan data \\
menggunakan wawancara, pengamatan dan dokumentasi. \\
informan yang menjadi sumber informasi yakni kepala \\
sekolah, wakil kepala sekolah, waka kurikulum, guru agama \\
dan pembina ekstrakurikuler. Hasil penelitian yakni: 1) \\
perencanaan pengembangan program pembelajaran \\
pendidikan agama islam dapat dilihat dalam bentuk \\
perangkat atau program pembelajaran yang meliputi \\
pengembangan silabus, rencana tahunan, program semester \\
dan persiapan mengajar dalam bentuk rencana pelaksanaan
\end{tabular}
\end{abstract}


pembelajaran yang disusun berdasarkan kajian standar kompetensi, kompetensi dasar dan indikator yang ditetapkan dengan berpijak pada standar isi, standar kompetensi lulusan mata pelajaran pendidikan agama islam. 2) Pelaksanaan pengembangan program pembelajaran yakni melaksanakan kegiatan pengembangan program pembelajaran, mengikuti prosedur yang berlaku di sekolah, yaitu dengan mengorganisasikan dan mengarahkan pengembangan program pembelajaran dengan mengacu pada pembelajaran intrakurikuler dan ekstrakurikuler. Penelitian ini juga menemukan bahwa pengendalian pelaksanaan program pembelajaran dilakukan dengan cara mengadakan evaluasi hasil belajar siswa dan monitoring kelas dalam pembelajaran intrakurikuler dan ekstrakurikuler.

\section{PENDAHULUAN}

Suatu kenyataan yang dihadapi dunia pendidikan khususnya Pendidikan Agama Islam di lembaga pendidikan formal saat ini, adalah rendahnya kualitas pembelajaran yang dilakukan oleh guru dan siswa di dalam kelas¹. Permasalahannya adalah proses pembelajaran Pendidikan Agama Islam kurang berhasil dalam pembentukan perilaku positif siswa. Lemahnya aspek metodologi yang dikuasai oleh guru juga merupakan penyebab rendahnya kualitas pembelajaran. Metode yang banyak dipakai adalah model konvensional yang kurang menarik².

Di samping itu ada juga yang merumuskan bahwa tujuan Pendidikan Agama Islam adalah membentuk peserta didik yang beriman dan bertakwa kepada Allah $\mathrm{SWT}^{3}$, memiliki pengetahuan yang luas tentang Islam dan berakhlakul karimah. ${ }^{4}$

1 Abdurrohman Abdurrohman dan Huldiya Syamsiar, "Pembelajaran Pendidikan Agama Islam (PAI) Model Keberagamaan Inklusif untuk Mencegah Radikalisme Beragama Dikalangan Siswa SMA," Fenomena 9, no. 1 (1 Juni 2017): 105, https://doi.org/10.21093/fj.v9i1.789; Muhammad Anas Ma'arif, “Analisis Konsep Kompetensi Kepribadian Guru PAI Menurut Az-Zarnuji," ISTAWA 2, no. 2 (2017): 35-60, http://journal.umpo.ac.id/index.php/istawa/article/view/624; Alfurqan Alfurqan dkk., "The Problematics of Islamic Religious Education Teacher In Using of Instructional Media at SD Negeri 06 Pancung Soal Pesisir Selatan," Al-Ta Lim Journal 26, no. 1 (28 Februari 2019): 56-64, https://doi.org/10.15548/jt.v26i1.526.

2 Syamsul Arifin, "Islamic religious education and radicalism in Indonesia: strategy of deradicalization through strengthening the living values education," Indonesian Journal of Islam and Muslim Societies 6, no. 1 (1 Juni 2016): 93, https://doi.org/10.18326/ijims.v6i1.93-126; Steve Young, "Islamic Education and the Public Sphere: Today's Pesantren in Indonesia - By Florian Pohl," Teaching Theology \& Religion 14, no. 3 (2011): 288-89, https://doi.org/10.1111/j.14679647.2011.00723.x.

3 Ah Zakki Fuad, "Rekonstruksi Tujuan Pendidikan Islam Berbasis Taksonomi Transenden," ISLAMICA: Jurnal Studi Keislaman 9, no. 2 (15 Maret 2016): 424-46,

Vol.2, No.1, January 2021

Tafkir: Interdisciplinary Journal of Islamic Education 
Permasalahan nyata yang tampak dan diakui pula oleh para ahli pendidikan dewasa ini adalah pendidikan agama yang diajarkan di sekolah umum ternyata kurang berhasil untuk mengembangkan pribadi-pribadi yang taat dan berakhlak mulia 5 . Bukti-bukti yang diajukan untuk memperkuat pernyataan tersebut antara lain kenyataan adanya siswa yang tidak mampu membaca Al-Qur'an dengan baik meski sudah duduk di bangku SMP, belum dapat melaksanakan shalat dengan baik, tidak puasa di bulan Ramadhan, tidak menunjukkan perilaku yang terpuji, banyaknya perilaku asusila dan penggunaan obat terlarang dan minum minuman keras di kalangan pelajar. Kesimpulannya, pendidikan agama belum mampu untuk menumbuhkan sikap positif dalam diri anak yang berguna bagi kemaslahatan masyarakat 6 .

Kegiatan evaluasi sering dilakukan dalam kehidupan sehari-hari tidak terkecuali dalam program pendidikan. Kegiatan dalam pendidikan dimulai dengan membuat perencanaan, melaksanakan program, dan kemudian mengevaluasi hasil pendidikan yang diperolehnya7 ${ }^{7}$ Pada intinya, mengevaluasi yaitu dengan menilai semua kegiatan untuk menemukan indikator yang menyebabkan sukses atau gagalnya pencapaian tujuan, sehingga dapat dijadikan bahan kajian selanjutnya bagi penentu kebijakan ${ }^{8}$.

https://doi.org/10.15642/islamica.2015.9.2.424-446; Imam Syafe'i, “Tujuan Pendidikan Islam,” Al-Tadzkiyyah: Jurnal Pendidikan Islam 6, no. 2 (2015): 151-66.

${ }^{4}$ Departemen Pendidikan Nasional, Pedoman Khusus Pengembangan Silabus dan Penilaian Mata Pelajaran Pendidikan Agama Islam SMP Kurikulum 2004, (Jakarta : Rancang Grafis, 2003), 2.

5 Muhammad Amri, Saharuddin Saharuddin, dan La Ode Ismail Ahmad, "The Implementation of Islamic Education: The Process of Instilling Akhlakul Karimah (Noble Characters) for Madrasah Tsanawiyah Students," Tadris: Jurnal Keguruan Dan Ilmu Tarbiyah 4, no. 1 (28 Juni 2019): 117-25, https://doi.org/10.24042/tadris.v4i1.4070; Syamsul Huda dkk., "The Relationship between Problem-Solving Ability and Students' Characters Based on Islamic Perspectives," Tadris: Jurnal Keguruan Dan Ilmu Tarbiyah 4, no. 2 (27 Desember 2019): 203-14, https://doi.org/10.24042/tadris.v4i2.5299.

6 Daradjat Zakiah, Dasar-dasar agama Islam: buku daras pendidikan agama Islam pada perguruan tinggi umum (Jakarta: Bulan Bintang, 1992); Zainal Arifin, "Pendidikan islam dalam perspektif filsafat ilmu," Ta'dib 19, no. 01 (2014): 123-42, http://jurnal.radenfatah.ac.id/index.php/tadib/article/view/12.

7 Muhammad Anas Ma`arif dan Ibnu Rusydi, "IMPLEMENTASI PENDIDIKAN HOLISTIK DI PONDOK PESANTREN AMANATUL UMMAH MOJOKERTO," EDUKASI: Jurnal Penelitian Pendidikan Agama Dan Keagamaan 18, no. 1 (27 April 2020), https://doi.org/10.32729/edukasi.v18i1.598.

${ }^{8}$ M. Hidayat Ginanjar, "Keseimbangan Peran Orang Tua Dalam Pembentukan Karakter Anak," Edukasi Islami: Jurnal Pendidikan Islam 2, no. 03 (8 Juni 2017), https://doi.org/10.30868/ei.v2i03.27. 
Mutu juga dapat diartikan sebagai konsep relatif. Karena mutu bukan atribut mutlak dari produk atau jasa, tetapi harus ditinjau dari berbagai segi termasuk misalnya; faktor objektivitas penilaian, atau pun tingkat kemampuan penilainya9 ${ }^{9}$

Mutu merupakan sebuah filosofi dan metodologi yang membantu intitusi untuk merencanakan perubahan dan mengatur agenda dalam menghadapi tekanantekanan dari luar yang olahan. Gambaran spesifikasi dan dalam memenuhi kebutuhan yang ditentukan, tersurat maupun tersirat. ${ }^{10}$ pembelajaran (learning) adalah perubahan perilaku yang relatif tetap yang muncul melalui pengalaman. Artinya, pembelajaran tidak hanya sekedar aktivitas, tetapi dia harus mendatangkan perubahan ${ }^{11}$.

Kenyataan di lapangan bahwa guru-guru agama (Islam), jarang yang mau mencermati efektivitas pengunaan metode mengajar, perhatiannya lebih terfokus pada buku pegangan (teks book) yang dipergunakan. Disamping itu, dalam mengajar kebanyakan guru agama, lebih dominan menggunakan metode ceramah, belum mampu mengembangkan program-program pembelajaran yang efektif dan aplikatif. Guru Agama belum banyak menggunakan manajemen pembelajaran yang profesional, masih banyak menggunakan paradigma lama yaitu pendidikan sebagai transfer ilmu saja belum pada pencapaian tiga ranah (kognitif, afektif, dan psikomototik) ${ }^{12}{ }^{13}$

Selama ini, metodologi pembelajaran agama Islam yang diterapkan masih mempertahankan cara-cara lama (tradisional) seperti ceramah, menghafal dan demonstrasi praktik ibadah yang tampak kering. Seperti halnya pada materi ilmu

9 Achmad Krisbiyanto, "Efektifitas Kepemimpinan Kepala Madrasah Terhadap Mutu Pendidikan MTsN 2 Mojokerto," Nidhomul Haq : Jurnal Manajemen Pendidikan Islam 4, no. 1 (10 Maret 2019): 52-69, https://doi.org/10.31538/ndh.v4i1.182; Anggun Wulan Fajriana dan Mauli Anjaninur Aliyah, "Tantangan Guru Dalam Meningkatan Mutu Pendidikan Agama Islam Di Era Melenial," Nazhruna: Jurnal Pendidikan Islam 2, no. 2 (11 Agustus 2019): 246-65, https://doi.org/10.31538/nzh.v2i2.324.

10 Yoga Anjas Pratama, "Implementasi Manajemen Pembelajaran Karakter Berbasis Total Quality Management Di SMP Muhammadiyah 3 Yogyakarta," Nidhomul Haq : Jurnal Manajemen Pendidikan Islam 4, no. 1 (7 Maret 2019): 1-22, https:/ / doi.org/10.31538/ndh.v4i1.184; Roelande H. Hofman dkk., "Educational Innovation, Quality, and Effects An Exploration of Innovations and Their Effects in Secondary Education," Educational Policy 27, no. 6 (1 November 2013): 84366, https://doi.org/10.1177/0895904811429288.

11 Syamsudin Syamsudin, Muhammad Hidayat Ginanjar, dan Moch Yasyakur, "Evaluasi Mutu Pembelajaran Pendidikan Agama Islam (pai) Di Smp Pembangunan Satu (pesat) Kota Bogor Tahun Ajaran 2017/2018," Prosa PAI : Prosiding Al Hidayah Pendidikan Agama Islam 1, no. 2B (3 Juli 2019): 167-78, https://doi.org/10.30868/ppai.v1i2B.468.

${ }_{12}$ Mohammad Surya, Psikologi Guru, Konsep dan Aplikasi, dari Guru untuk Guru, (Bandung: Alfabeta, 2013), 23.

${ }_{13}$ Muhaimin, Pengembangan Kurikulum Pendidikan Agama Islam, Cet. 5 (Jakarta: Raja Grafindo Persada, 2012).

Vol.2, No.1, January 2021

Tafkir: Interdisciplinary Journal of Islamic Education 
tajwid dari masa kemasa selalu menggunakan cara-cara lama dengan ceramah dan membaca Al-Qur'an sehingga cara-cara seperti itu diakui atau tidak, membuat siswa tampak bosan, jenuh dan kurang bersemangat dalam belajar ${ }^{14}$.

Oleh karenanya secara umum seluruh praktisi pendidikan, khususnya pendidikan agama Islam perlu melakukan inovasi, kreatifitas sehingga tujuan pendidikan Islam dapat tercapai. Strategi PAIKEM merupakan pendekatan dalam proses belajar mengajar yang bila diterapkan secara tepat berpeluang dalam meningkatkan tiga hal, pertama, maksimalisasi pengaruh fisik terhadap jiwa, kedua, maksimalisasi pengaruh jiwa terhadap proses psikofisik dan psikososial,dan ketiga, bimbingan ke arah pengalaman kehidupan spiritual.

Untuk itulah dibutuhkan suatu program pengembangan pembelajaran Pendidikan Agama Islam yang didalamnya diarahkan bukan hanya sekedar menyuruh siswa untuk menghafal nilai-nilai normatif, disampaikan lewat ceramah dan diakhiri dengan ulangan, tetapi program pengembangan Pendidikan Agama Islam yang mengarahkan siswa tidak hanya memahami berbagai konsep, tetapi mereka mampu menguasai keterampilan berpikir, karena memang seharusnya learning itu berisi thinking dan juga values. Disamping itu seorang guru agama harus pandai membuat perencanaan yang mengarah pada pengembangan ke arah yang lebih baik.

\section{METODE PENELITIAN}

Fokus Penelitian adalah Manajemen Pengembangan Program Pembelajaran Pendidikan Agama Islam di SMP Nizhamul Islam Desa Pegalangan Kidul Kecamatan Maron Kabupaten Probolinggo. Untuk menjawab fokus penelitian tersebut dibutuhkan subfokus yang mempertanyakan bagaimana proses perencanaan, pelaksanaan, dan pengendalian program pembelajaran Pendidikan Agama Islam. Fokus penelitian yang demikian berbentuk eksplanatori dan lebih mengarah kepenggunaan strategi studi kasus $^{15}$.

14 Moch Sya'roni Hasan dan Nikmawati Nikmawati, "Model Pembelajaran Pai Dalam Membentuk Kepribadian Islami Siswa Di Smk Dr Wahidin Sawahan Nganjuk," TA'LIM : Jurnal Studi Pendidikan Islam 3, no. 1 (7 Januari 2020): 1-21, http://www.ejurnal.unisda.ac.id/index.php/talim/article/view/1751; Tri Hartono dan Dhenis Agus Saputro, "Pengembangan Desain Pembelajaran PAI Di Pondok Pesantren Kreatif Agro Nuur ElFalah Salatiga," Nazhruna: Jurnal Pendidikan Islam 2, no. 2 (26 Agustus 2019): 290-309, https://doi.org/10.31538/nzh.v2i2.331.

${ }^{15}$ Robert K Yin, Case Study Research: Design and Methods, 2013.

Vol.2, No.1, January 2021

Tafkir: Interdisciplinary Journal of Islamic Education 
Studi kasus sendiri merupakan bagian dari penelitian kualitatif ${ }^{16}$. Jadi penelitian ini menggunakan jenis kualitatif dengan pendekatan desain studi kasus (single case and situs). Alasan digunakannya pendekatan kualitatif sebagai pendekatan penelitian ini adalah karena peneliti melihat sifat dari masalah yang diteliti dapat berkembang secara alamiah sesuai dengan kondisi dan situasi di lapangan. Peneliti juga berkeyakinan bahwa dengan pendekatan alamiah, penelitian ini akan menghasilkan informasi yang lebih kaya.

Metode untuk menggali data adalah dengan wawancara, observasi dan partisipan observation. Wawancara dengan Kepala Sekolah, guru Pendidikan Agama Islam, siswa dan beberapa staff pendidikan.

\section{HASIL DAN PEMBAHASAN}

\section{Perencanaan Pengembangan Program Pembelajaran Pendidikan Agama Islam}

Berdasarkan pada paparan data penelitian sebelumnya dapat dikemukakan beberapa temuan penelitian diantaranya yaitu bahwa, Perencanaan pengembangan program pembelajaran PAI di SMP Nizhamul Islam dapat dilihat dalam bentuk perangkat atau program pembelajaran yang meliputi: pengembangan silabus bidang studi PAI, rencana tahunan, program semester dan persiapan mengajar dalam bentuk Rencana Pelaksanaan Pembelajaran (RPP. Rencana pengembangan program pembelajaran disusun berdasarkan kajian SK-KD dan indikator yang ditetapkan dengan berpijak pada Standar Isi (SI), Standar Kompetensi Lulusan (SKL) mata pelajaran PAI yang tertuang dalam PP. 19/2005 dan permendiknas nomor 22 (SI) dan nomor 23 (SKL), serta nomor 24 (Pelaksanaan permendiknas no. 22 dan 23) tahun 2006.

Penelitian ini juga menemukan bahwa perencanaan pengembangan program pembelajaran Pendidikan Agama Islam dimulai dengan menyusun pengembangan Silabus dan sistem penilaiannya. Adapun teknis pengembangan silabus yang dilakukan oleh sekolah adalah dengan cara mengajak semua guru melakukan rapat kerja khusus, dimulai dengan pemberian orientasi dan pengarahan dari kepala sekolah, dilanjutkan dengan orientasi dari nara sumber, kemudian diteruskan pada orientasi dan diskusi, semua guru diberi waktu untuk membuat pengembangan silabus mata pelajaran yang dibinanya secara berkelompok sesuai dengan mata

${ }^{16}$ John W. Creswell, Qualitative inquiry \& research design: choosing among five approaches, 2nd ed (Thousand Oaks: Sage Publications, 2007). 
pelajaran yang dipegang agar diketahui tingkat pemahaman mereka, kemudian diadakan penilaian kembali untuk presentasi dihadapan semua peserta. Setelah usai, semua guru diminta menyempurnakan pengembangan silabus, dan harus sudah jadi sebelum memasuki tahun pelajaran baru.

Berdasarkan dokumentasi, pada data rencana pelaksanaan pembelajaran (RPP) semua guru PAI di SMP Nizhamul Islam, ada kesamaan dalam struktur dan kegiatan yang tercantum di dalamnya. Bentuk perencanaan pembelajaran dengan konsep kurikulum sama halnya dengan perencanaan konsep kurikulum pelajaran yang lain, diantaranya menyusun kegiatan perencanaan pengajaran sistematis dan mengidentifikasi konsep-konsep yang akan dibahas serta memilih kegiatan pembelajaran yang sesuai.

Dalam kenyataan, walaupun masing-masing guru memiliki pendapat yang sama tentang perencanaan pengajaran, namun dalam realisasinya berbeda. Hal itu tampak dari penerapan di dalam kelas, utamanya dalam aplikasi metode pembelajaran. Semua guru menyusun kegiatan secara sistematis berupa RPP, namun dalam penerapan di kelas tidak jarang tidak sesuai dengan apa yang dituliskan dalam RPP. Banyak faktor yang mempengaruhi fakta tersebut, bisa jadi karena waktu, kemampuan guru, keadaan siswa, media dan suasana dalam kelas.

Selanjutnya, dalam penyusunan Rencana tahunan, program semester dan silabus ternyata belum dapat digunakan secara langsung untuk melaksanakan kegiatan pembelajaran. Oleh karena itu perlu dibuat rencana pelaksanan Pembelajaran (RPP), yang merupakan implementasi program pembelajaran yang sudah dituangkan di dalam silabus.

Temuan mengenai kegiatan perencanaan pengembangan program pembelajaran Pendidikan Agama Islam di SMP Nizhamul Islam.

\section{Pelaksanaan Pengembangan Program Pembelajaran Pendidikan Agama Islam}

Berdasarkan pemaparan data tersebut di atas peneliti menemukan bahwa dalam melaksanakan kegiatan pengembangan program pembelajaran PAI, mengikuti prosedur yang berlaku di SMP Nizhamul Islam, yaitu dengan mengorganisasikan dan mengarahkan pengembangan program pembelajaran dengan mengacu pada pembelajaran Intrakurikuler dan Ekstrakurikuler serta pembiasaan Imtaq dan pembudayaan suasana religius. 


\section{Program Kegiatan Tatap Muka (Pembelajaran Intrakurikuler PAI)}

Dalam peneitian ini ditemukan bahwa pengorganisasian dan pengarahan pengembangan program pembelajaran intrakurikuler PAI di SMP Nizhamul Islam mengikuti prosedur yang ditetapkan oleh kurikulum yang mengacu pada KTSP SMP Nizhamul Islam.

Terkait dengan pengorganisasian materi pembelajaran PAI, diperoleh data dokumen yang menyatakan bahwa secara garis besar materi pembelajaran PAI dikelompokkan menjadi lima aspek yaitu Al-Qur'an/Hadis, aspek aqidah, aspek akhlak, aspek ibadah.

Dalam menetapkan guru yang akan mengajar mata pelajaran PAI, SMP Nizhamul Islam juga mengikuti prosedur yang telah ditetapkan oleh koordinator kurikulum dengan melihat SK pengangkatan dari Dinas Pendidikan atau Departemen Agama dengan ketentuan bahwa yang merencanakan dan menentukan guru yang akan mengajar PAI di kelas adalah koordinator kurikulum dengan melihat SK pengangkatan dari Dinas Pendidikan atau Departemen Agama, kecuali jika dirasa kurang memenuhi kebutuhan sekolah, maka diangkatlah Guru Tidak Tetap (GTT) oleh Kepala Sekolah dengan mempertimbangkan usulan dari Dewan Guru. sedangkan untuk pengajar ekstrakurikuler ditentukan oleh koordinator kesiswaan

Penelitian ini juga menemukan bahwa prosedur pengorganisasian, pelaksanaan dan pengarahan pengembangan program pembelajaran PAI di SMP Nizhamul Islam tersebut nampaknya telah disepakati melalui kerjasama tim antara koordinator kurikulum dengan koordinator kesiswaan SMP Nizhamul Islam dengan mengacu pada tugas pokok dan fungsi (Tupoksi) urusan kurikulum dan kesiswaan yang ada di SMP Nizhamul Islam.

Berkaitan dengan prosedur distribusi guru mata pelajaran Pendidikan Agama Islam (PAI), diperoleh informasi bahwa penentuan guru mata pelajaran PAI diserahkan kepada urusan kurikulum. Sedangkan untuk guru ekstrakurikuler diserahkan kepada koordinator kesiswaan dengan pertimbangan koordinator ekstrakurikuler. Karena dari merekalah secara persis tahu karakteristik guru yang mengajar dan materi yang diajarkan.

Terkait dengan pembagian jam mengajar Pendidikan Agama Islam untuk tahun pelajaran 2019/2020 ini, Pak Misbah mengajar PAI kelas VII, VIII dan IX, 
ditambah ekstra dan Pembina OSIS bidang ketaqwaan.

Terkait dengan pengaturan beban jam mengajar ini, diperoleh informasi bahwa Untuk program pembelajaran Intrakurikuler Pendidikan Agama Islam (PAI) diatur sesuai dengan SK mengajar bagi guru-guru PAI. Dilihat dari pembagian jamnya, masing-masing guru Agama Islam mestinya mendapat jam mengajar sama.

Dalam melaksanakan pembelajaran PAI di kelas, guru PAI menggunakan tahapan-tahapan sebagaimana dijelaskan dalam temuan peneliti melalui observasi sebagai berikut:

\section{Kegiatan awal (pendahuluan)}

Model pembelajaran yang lazim digunakan diselenggarakan oleh Guru PAI di kelas VIII dimulai dengan berdoa bersama, kemudian dilanjutkan Kultum (kuliah tujuh menit) atau semacam ceramah singkat dari Guru. Kegiatan kultum ini dilaksanakan secara rutin dengan tujuan siswa diberi bekal untuk menyerap materi yang akan dipelajari pada saat itu. Tentu saja guru harus pandai-pandai mengaitkan materi kultum dengan materi yang akan dipelajari. Kegiatan ini dilaksanakan pada tiap pertemuan jam pelajaran agama Islam.

Setelah kultum, selanjutnya pembacaan Al-Qur'an secara berjamaah dipimpin oleh siswa yang bertugas secara bergiliran yang jadwalnya sudah diatur oleh ketua kelas. Kemudian dilanjutkan dengan penjelasan dari guru tentang kandungan ayat yang tersirat di dalamnya, kemudian dihubungkan dengan materi yang akan dipelajari yang diselingi dengan pertanyaan secara bergiliran kepada setiap siswa.

Pertanyaan guru, terkadang mengenai batas materi yang telah dipelajari pada pertemuan sebelumnya, terkadang juga bertanya tentang materi yang terkait dengan pelajaran sebelumnya. Hal ini tentunya merupakan strategi guru dalam mengawali pembelajaran, yang bertujuan menarik perhatian siswa, mengetahui tingkat penguasaan materi sebelumnya dan juga untuk mengetahui kesiapan siswa dalam mengikuti pelajarannya.

Dalam penjelasan kandungan ayat, guru juga sering menghubungkannya dengan kejadian sosial dan fenomena alam yang menjadi trend saat itu untuk menghindari kebosanan dalam pembelajaran agama di kelas, mengingat tingkat kemampuan berfikir pada pengetahuan umum lebih mendominasi dalam pembelajaran di SMP Nizhamul Islam. Sebagai contohnya, ketika guru menjelaskan 
kompetensi al Qur'an tentang ayat yang berhubungan dengan kebaikan pada QS. al Insyirokh ayat 1-8, disitu guru menghubungkannya dengan fenomena di sebagian masyarakat yang mengalami kesempitan hidup karena bencana alam seperti meluapnya Lumpur Lapindo Brantas di Sidoarjo atau gempa di Yogyakarta, yang nota bene membutuhkan uluran tangan dari para orang kaya, untuk mengeluarkan sebagian hartanya demi membantu mereka yang membutuhkan tersebut.

Selain itu, dalam observasi ditemukan, guru pada kegiatan awal ini, jika sempat memberi tugas pada siswa pada tatap muka sebelumnya, guru terlebih dahulu memeriksa dan mengembalikan pekerjaan rumah siswa serta mengomentari jawaban mereka. Komentar ini tentunya dalam rangka mengoreksi (meluruskan) jika jawaban mereka kurang tepat. Sesekali dalam komentar guru juga, dalam bentuk reward verbal jika terdapat jawaban siswa yang sudah tepat.

\section{Kegiatan Inti}

Dalam kaitannya dengan kegiatan inti pembelajaran, terdapat berbagai teknik dan cara yang ditemui pada penyampaian pembelajaran PAI oleh masing-masing guru di SMP Nizhamul Islam. Pada kelas IX misalnya, setelah guru mengadakan kegiatan awal seperti kultum, tadarrus, dan penjelasan makna yang terkandung dalam ayat, guru kemudian menjelaskan beberapa konsep-konsep dan pokok-pokok materi yang telah dipersiapkan sebelumnya.

Pada pertemuan perdana, guru menjelaskan tentang konsep-konsep dan garis besar pokok materi, yang kemudian sering diselingi dengan lontaran pertanyaanpertanyaan yang menantang siswa untuk mengeluarkan pendapatnya. Hampir sering terlihat dalam aktifitas pembelajaran muncul pertanyaan yang sifatnya terbuka sehingga memotivasi siswa untuk mengeluarkan pendapatnya.

Selanjutnya, guru membagi tugas dengan tema atau kompetensi/sub kompetensi yang berbeda-beda sesuai dengan target kurikulum pada kelas IX, yang dibagi dalam beberapa kelompok, untuk didiskusikan pada pertemuan berikutnya, yang tentunya terkait dengan kompetensi yang telah dijelaskan.

Dalam pembelajaran di kelas IX, ada sesuatu yang unik dalam pembelajarannya, yaitu dengan menggunakan metode diskusi yang sifatnya menantang kreativitas siswa. Bentuk rangsangan dan tantangan ini tentunya bersifat akademis. Guru memotivasi siswa untuk dapat tampil menjadi kelompok 'the 
excellence' lewat diskusi di kelas. Kriteria penilaian sebagai kelompok terbaik ini, dengan melihat bahasan dan isi makalah dan penampilan kelompok dalam presentasi makalah. Selanjutnya kelompok yang tergolong 'the excellence' akan mewakili kelasnya untuk mempresentasikan makalah terbaiknya dihadapan seluruh teman-temannya yang muslim (terutama kelas IX), pada pelajaran pembiasaan Imtaq yang diselenggarakan setiap Jumat siang satu jam pelajaran menjelang pulang.

\section{Kegiatan Akhir (penutup)}

Kegiatan ini adalah kegiatan untuk memberikan penegasan atau kesimpulan dan penilaian terhadap penguasaan bahan kajian yang diberikan pada kegiatan inti. Pada kegiatan ini dapat dilakukan kegiatan tindak lanjut berupa pekerjaan rumah dan lain-lain.

Pada kegiatan akhir, hampir semua guru PAI di SMP Nizhamukl Islam tidak memiliki perbedaan dalam pembelajarannya. Pada dasarnya kedua guru pada akhir pembelajaran memberikan penegasan dan kesimpulan serta penilaian terhadap penguasaan bahan kajian yang diberikan pada kegiatan inti.

Adapun penilaian akhir (post test), guru melakukannya dalam bentuk tanya jawab tentang apa yang belum dipahami oleh siswa. Hal-hal yang belum dipahami siswa, guru meminta siswa untuk ditanyakan, namun jika tidak ada yang bertanya dianggap sudah paham atau terkadang guru pun berbalik melontarkan pertanyaan kepada siswa secara bergiliran.

Penilaian akhir dalam bentuk pemberian tugas rumah atau pekerjaan rumah (PR) tidak jarang terjadi. Guru memberikan tugas kepada siswa untuk dikerjakan di rumah mereka masing-masing, misalnya saja tugas untuk menuliskan kembali ayatayat Al-Qur'an yang baru saja dijelaskan dan menjelaskan tajwid yang ada dalam ayat tersebut. Hal ini bermaksud untuk mengetahui sejauh mana penguasaan materi yang telah dijelaskan dan melatih siswa mencapai kompetensi tertentu seperti mampu menuliskan ayat AlQur'an, dan lain sebagainya.

Selanjutnya pada kegiatan akhir, tindak lanjut dari penjelasan tentang pokokpokok materi pembelajaran dilakukan dalam bentuk pembagian tugas kelompok. Masing-masing kelompok mendapatkan judul atau tema (kompetensi atau sub kompetensi) yang berbedabeda, untuk dipresentasikan pada minggu berikutnya sesuai dengan jadwal yang diatur oleh guru. 


\section{Program Kegiatan Tugas Terstruktur (Pembelajaran Ekstrakurikuler PAI)}

Kegiatan tugas terstruktur dalam bentuk ekstrakurikuler termasuk kategori program pengembangan diri, merupakan kegiatan di luar jam yang tercantum pada struktur kurikulum. Kegiatan ekstrakurikuler ditujukan untuk mengembangkan bakat dan minat serta untuk memantapkan pembentukan kepribadian siswa. Kegiatan ekstrakurikuler yang ada di SMP Nizhamul Islam dilaksanakan dengan menyesuaikan kebutuhan sekolah yang menunjang pembelajaran di kelas serta anggaran biaya yang ada.

Dalam penelitian ini ditemukan bahwa program kegiatan tugas terstruktur dalam bentuk pembelajaran ekstrakurikuler yang dikembangkan di SMP Nizhamul Islam adalah Baca Tulis Al-Qur'an (BTA) yang pelaksanaannya menggunakan model menirukan bacaan yang diperankan oleh pembinanya dengan sesekali bertanya tentang ilmu tajwidnya atau cara membaca makhroj yang benar. Cara semacam ini persis seperti model yang diterapkan di pesantren tetapi siswa diberi waktu untuk bertanya jawab dengan Pembina.

Dalam prakteknya, peserta ekstrakurikuler BTA ini sangat antusias mengikuti kegiatan terbukti dengan absensi kehadiran peserta. Disamping itu kegiatan ini dilaksanakan di tempat Mushollah sekolah sehingga pelaksanannya dengan mudah dapat dikendalikan.

Penelitian ini juga menemukan bahwa cara mengatur program pembelajaran ekstrakurikuler seperti yang tercantum dalam mekanisme kegiatan pengembangan diri dicantumkan dalam jadwal tersendiri yang diatur oleh kurikulum seperti di bawah ini: a) Kegiatan Pengembangan Diri yang bersifat rutin/terstruktur dilaksanakan pada waktu pembelajaran efektif dengan mengalokasikan waktu khusus dalam jadwal pelajaran, dibina oleh guru dan konselor sekolah. b) Kagiatan Pengembangan Diri pilihan dilaksanakan di luar jam pembelajaran (ekstrakurikuler) dibina oleh guru, praktisi, atau alumni yang memiliki kualifikasi yang baik berdasarkan surat keputusan kepala sekolah. Dalam penelitian ini ditemukan juga bahwa pengembangan program dalam bentuk kegiatan tugas terstruktur di SMP Nizhamul Islam adalah Pembiasaan IMTAQ yang dikoordinasi oleh kurikulum, dilaksanakandi kelas dengan I jam pelajaran dibina oleh wali kelas masing-masing. Materi yang diajarkan adalah terkait dengan bacaan surat-surat pendek dalam 
AlQur,an dan do'a-do'a. hasil yang diharapkan dari kegiatan ini adalah siswa bisa hafal dengan fasikh dari ayat dan do'a-do'a harian.

\section{Pengendalian Pengembangan Program Pembelajaran Pendidikan Agama Islam Program Kegiatan Tatap Muka (Pembelajaran Intrakrikuler PAI)}

Dalam melaksanakan kegiatan pengendalian pengembangan program pembelajaran PAI yakni program pembelajaran intrakurikuler PAI SMP Nizhamul Islam melibatkan berbagai pihak. Yaitu dilakukan setiap satu bulan sekali. Dimana kepala sekolah beserta staf wajib mengikuti rapat khusus sebelum diadakan rapat umum beserta dewan guru dan karyawan yang ada di SMP Nizhamul Islam. Biasanya membahas tentang evaluasi pelaksanaan program-program pembelajaran secara menyeluruh, mulai dari masalah di kelas sampai pada hal-hal yang terkait dengan pengembangan program sekolah secara keseluruhan.

Penelitian ini juga menemukan bahwa Pengendalian pelaksanaan program pembelajaran PAI di SMP Nizhamul Islam dilakukan dengan cara mengadakan evaluasi hasil belajar siswa dan monitoring kelas dalam pembelajaran intrakurikuler dan ekstrakurikuler.

Untuk pembelajaran secara umum di Kelas kepala sekolah melakukan pengendalian dalam bentuk supervisi kelas dengan cara melakukan pembinaanpembinaan terhadap proses pelaksanaan KBM pada saat itu. Jika tidak masuk kelas, kepala sekolah melakukannya dengan cara menilainya melalui perangkat pembelajaran yang dibuat oleh guru yang bersangkutan ${ }^{17}$. Cara yang kedua adalah dengan supervisi secara klinis ${ }^{18}$, yaitu melakukan pembinaan kepada guru yang bersangkutan baik dilakukan di ruang kepala sekolah maupun dalam rapat dinas dewan guru. Cara seperti ini diharapkan yang datang secara aktif adalah gurunya bukan kepala sekolahnya. Hal dilakukan untuk mencari permasalahanpermasalahan

17 Santi Andriyani dan Abdulloh Hamid, "Implementasi Strategi Pembelajaran Multiple Intelligences Pada Mata Pelajaran PAI Studi Kasus Di SD Semai Jepara," Proceedings of Annual Conference for Muslim Scholars, no. Seri 2 (14 Mei 2017): 824-34, http://proceedings.kopertais4.or.id/index.php/ancoms/article/view/84; Najwan Saada dan Haneen Magadlah, "The meanings and possible implications of critical Islamic religious education," British Journal of Religious Education 0, no. $0 \quad$ (25 Juni 2020): 1-12, https://doi.org/10.1080/01416200.2020.1785844.

18 Saiful Asyari, "Supervisi Kepala Madrasah Berbasis Penilaian Kinerja Sebagai Upaya Peningkatan Profesionalitas Guru," JIEMAN: Journal of Islamic Educational Management 1, no. 2 (24 Juni 2020): 149-63, https://doi.org/10.35719/jieman.v1i2.14; Abd Kadim Masaong, Supervisi pembelajaran dan pengembangan kapasitas guru (Bandung: Alfabeta, 2013). 
yang terjadi sepanjang proses dan hasil pembelajaran di kelas.

Selanjutnya ditemukan juga bahwa ketika melaksanakan pembelajaran PAI di kelas, kepala sekolah juga pernah mengadakan supervisi terhadap cara mengajar guru Agama Islam di kelas. Juga tidak jarang dilakukan dengan cara bekerjasama dengan Pengawas Pendidikan Agama Islam dari Depag. Seperti yang sudah-sudah bahwa wilayah Pendidikan Agama Islam memang harus ditangani oleh Depag dan dari depag sendiri sudah ditentukan pengawasnya, kepala sekolah hanya melihat dari sisi administrasinya saja. Nampaknya masalah pengendalian pembelajaran PAI ini memang diatur sesuai dengan pengawas mata pelajaran.

Kegiatan pengendalian program pembelajaran PAI ini juga dilakukan oleh guru Agama Islam . dengan cara menilai pembelajaran di kelas dan mengontrol kegiatan keagamaan. Yang tidak hanya menekankan pada aspek kognitif saja tetapi juga afektif dan psikhomotorik.

Penelitian ini juga menemukan bentuk pengendalian melalui ujian tulis dan praktek dengan menggunakan fasilitas masjid dan ruang-ruang khusus agama. Untuk kegiatan praktek ibadah.

Kegiatan pengendalian pengembangan program pembelajaran PAI melalui penilaian hasil belajar siswa di SMP Nizhamul Islam dilakukan dengan mengkuti prosedur yang sudah diatur dalam pedoman penilaian PAI yang diterbitkan oleh BSNP yaitu dengan Tugas-tugas, Ulangan Harian (UH), Ulangan Tengah Semester (UTS), dan ulangan akhir semester (UAS) atau dikenal dengan UKK (Ujian Kenaikan Kelas) khusus semester genap, juga penilaian afektif dan psichomotor yang diatur dalam penilian akhlak.

Penelitian ini juga menemukan untuk penilaian Mata Pelajaran PAI, evaluasi pembelajarannya menggunakan model yang sudah ditetapkan oleh BSNP yaitu ada ujian tulis dan praktek. Yang termasuk ujian tulis diambilkan dari ulangan harian, ulangan tengah semester dan ulangan akhir semester. Sedangkan untuk ujian praktek diambilkan dari praktek-praktek keagamaan yang sudah diprogramkan di sekolah seperti rajin sholat wajib dzuhur dan jum'at di sekolah ditambah penilaian akhlak. Penilaian akhlak ini menyangkut; afektif dan psikhomotorik siswa. Untuk penilaian ujian praktek membaca AlQur'an yang dinilai adalah makhroj, tajwid, dan kelancaran baca. 
Berdasarkan dokumen ujian praktek yang diselenggarakan di sekolah, untuk kelas IX biasanya mempraktekkan sholat dan membaca Al-Qur'an. Teknis pelaksanaannya dengan membagikan kartu yang berisi soal yang akan dipraktekkan dengan cara siswa mengambilnya dari penguji saat itu juga.

Semua bentuk pengendalian yang dilakukan di SMP Nizhamul Islam mengacu pada Kriteria kenaikan kelas. Untuk PAI harus mencapai minimal. jika tidak memenuhinya, maka dilakukan program remedial. Karena itu, ujian tulis maupun praktek dilaksanakan oleh Guru PAI dan sekolah dengan menggunakan nilai angka. Standar kelulusan yang digunakan adalah minimal mencapai. jika belum mencapai ketentuan tersebut, siswa harus mengikuti program remedial yang jadwalnya ditentukan oleh kurikulum.

\section{Program Kegiatan Tugas Terstruktur (Pembelajaran Ekstrakurikuler PAI)}

Bentuk pengendalian Kegiatan ekstrakurikuler PAI di SMP Nizhamul Islam dirancang untuk dijadikan media pelatihan yang mendukung pembelajaran PAI di kelas dan pembiasaan bagi siswa untuk mengamalkan ajaran-ajaran agama Islam dalam kehidupan sehari-hari. Oleh karena itu, pengendaliannya hanyalah keaktifan siswa dalam mengikuti kegiatan melalui pengamatan dan daftar hadir serta prestasi yang dicapai.

Penelitian ini juga menemukan bahwa untuk ekstra Pendidikan Agama Islam di SMP ini dikembangkan program TPA dengan nama BTA (Baca Tulis Al-Qur'an), sedangkan untuk pengendaliannya juga lewat supervise kegiatan dengan melihat semacam silabus yang dibuat dan daftar hadir Pembina ekstra. ada lagi kegiatan yang sudah terprogram dan masuk dalam struktur kurikulum yaitu pembiasaan IMTAQ diisi oleh wali kelasnya masing-masing. Nah kegiatan IMTAQ ini untuk sementara tujuannya supaya anak-anak terbiasa saja dalam melafalkan do'a-do'a harian dan ayatayat pendek dalam Al-Qur'an. Adapaun cara pengendaliannya tidak ada evaluasi hanya pada daftar hadir wali kelas pada jam tersebut.

Diperoleh informasi bahwa kegiatan pembelajaran PAI di SMP diadakan praktek pembiasaan budaya religius dan kegiatan ekstrakurikuler keagamaan seperti BTA, pesantren romadhon dan peringatan hari besar Islam lainnya. Hal ini dimaksudkan agar para siswa berlatih dan terbiasa mepraktekkan ilmuilmu keislaman yang sudah diketahuinya dalam kehidupan sehari-hari. 
Jadi dengan demikian diperoleh kesimpulan bahwa bentuk pengendalian dari semua kegiatan yang berkaitan dengan ekstrakurikuler yang ada di SMP Nizhamul Islam adalah dengan melihat daftar hadir Pembina, silabus yang dibuat, dan prestasi yang diraih. kepala sekolah juga berharap agar dikembangkan bentuk-bentuk keteladanan pada anak-anak seperti bersikap ramah, sopan-santun dan terbiasa berbusana muslim.

Kegiatan-kegiatan yang mendukung terhadap keberhasilan pembelajaran pendidikan Agama Islam dapat dilihat juga dalam kegiatan yang ditangani oleh Pembina Osis bidang ketaqwaan, dalam hal ini yang menangani adalah Pak Misbah dan Pak Jamal. Melalui kegiatan ini disusun program peningkatan ketaqwaan lewat OSIS. Adapun kegiatannya adalah Sholat Jum'at di sekolah, Pesantren Romadhon, dan lain-lain. Adapun bentuk pengendaliannya melalui monitoring dan daftar kehadiran siswa dan pembina.

\section{KESIMPULAN}

Berdasarkan hasil paparan data dan analisis pada bab sebelumnya, maka dapat disimpulkan bahwa :

Perencanaan pengembangan program pembelajaran PAI di SMP Nizhamul Islam dapat dilihat dalam bentuk perangkat atau program pembelajaran yang meliputi: pengembangan silabus bidang studi PAI, rencana tahunan, program semester dan persiapan mengajar dalam bentuk Rencana Pelaksanaan Pembelajaran (RPP. Melaksanakan kegiatan pengembangan program pembelajaran PAI, mengikuti prosedur yang berlaku di SMP Nizhamul Islam, yaitu dengan mengorganisasikan dan mengarahkan pengembangan program pembelajaran dengan mengacu pada pembelajaran Intrakurikuler dan Ekstrakurikuler. Pelaksanaan pengembangan Program pembelajaran dapat dikategorikan dalam beberapa tahapan kegiatan yaitu: kegiatan awal, kegiatan inti dan kegiatan akhir pembelajaran.

Pengendalian program pembelajaran PAI di SMP Nizhamul Islam dapat dilakukan dengan dua cara. Pertama dengan menilai program, proses dan hasil pengembangan program pembelajaran dan kedua dengan melakukan pengawasan atau kontrol terhadap program-program yang dikembangkan. Penilaian program dimaksudkan untuk mengetahui sejauh mana keterlaksanaan kegiatan belajar mengajar (KBM) secara keseluruhan. Penilaian ini dilakukan dengan cara 
membandingkan perencanaan yang telah disusun dengan pelaksanaannya. Penilaian ini mencakup penilaian terhadap rencana tahunan, semester dan persiapan mengajar. Penilaian dapat dilakukan oleh guru, kepala sekolah dan Pembina lainnya. Penilaian hasil belajar siswa dan pelaksanaan kegiatan belajar mengajar, dapat menjadi masukan bagi penilaian ini. Hasil penilaian ini digunakan penyempurnaan dan pengembangan program selanjutnya.

\section{REFERENSI}

Abdurrohman, Abdurrohman, dan Huldiya Syamsiar. “Pembelajaran Pendidikan Agama Islam (PAI) Model Keberagamaan Inklusif untuk Mencegah Radikalisme Beragama Dikalangan Siswa SMA." Fenomena 9, no. 1 (1 Juni 2017): 105. https:// doi.org/10.21093/fj.v9i1.789.

Alfurqan, Alfurqan, M. Tamrin, Zulvia Trinova, dan Zuhdiyah Zuhdiyah. "The Problematics of Islamic Religious Education Teacher In Using of Instructional Media at SD Negeri 06 Pancung Soal Pesisir Selatan." Al-Ta Lim Journal 26, no. 1 (28 Februari 2019): 56-64. https:/ / doi.org/10.15548/jt.v26i1.526.

Amri, Muhammad, Saharuddin Saharuddin, dan La Ode Ismail Ahmad. "The Implementation of Islamic Education: The Process of Instilling Akhlakul Karimah (Noble Characters) for Madrasah Tsanawiyah Students." Tadris: Jurnal Keguruan Dan Ilmu Tarbiyah 4, no. 1 (28 Juni 2019): 117-25. https://doi.org/10.24042/tadris.v4i1.4070.

Andriyani, Santi, dan Abdulloh Hamid. "Implementasi Strategi Pembelajaran Multiple Intelligences Pada Mata Pelajaran PAI Studi Kasus Di SD Semai Jepara." Proceedings of Annual Conference for Muslim Scholars, no. Seri 2 (14 Mei 2017): 824-34.

http:// proceedings.kopertais4.or.id/index.php/ancoms/article/view/84.

Arifin, Syamsul. "Islamic religious education and radicalism in Indonesia: strategy of de-radicalization through strengthening the living values education." Indonesian Journal of Islam and Muslim Societies 6, no. 1 (1 Juni 2016): 93. https://doi.org/10.18326/ijims.v6i1.93-126.

Arifin, Zainal. "Pendidikan islam dalam perspektif filsafat ilmu." Ta'dib 19, no. 01 (2014):

http://jurnal.radenfatah.ac.id/index.php/tadib/article/view/12. 
Asyari, Saiful. "Supervisi Kepala Madrasah Berbasis Penilaian Kinerja Sebagai Upaya Peningkatan Profesionalitas Guru." JIEMAN: Journal of Islamic Educational Management 1, no. 2 (24 Juni 2020): 149-63. https://doi.org/10.35719/jieman.v1i2.14.

Creswell, John W. Qualitative inquiry E research design: choosing among five approaches. 2nd ed. Thousand Oaks: Sage Publications, 2007.

Fajriana, Anggun Wulan, dan Mauli Anjaninur Aliyah. “Tantangan Guru Dalam Meningkatan Mutu Pendidikan Agama Islam Di Era Melenial." Nazhruna: Jurnal Pendidikan Islam 2, no. 2 (11 Agustus 2019): 246-65. https://doi.org/10.31538/nzh.v2i2.324.

Fuad, Ah Zakki. "Rekonstruksi Tujuan Pendidikan Islam Berbasis Taksonomi Transenden." ISLAMICA: Jurnal Studi Keislaman 9, no. 2 (15 Maret 2016): 424-46. https:// doi.org/10.15642/islamica.2015.9.2.424-446.

Ginanjar, M. Hidayat. “Keseimbangan Peran Orang Tua Dalam Pembentukan Karakter Anak." Edukasi Islami: Jurnal Pendidikan Islam 2, no. 03 (8 Juni 2017). https://doi.org/10.30868/ei.v2i03.27.

Hartono, Tri, dan Dhenis Agus Saputro. “Pengembangan Desain Pembelajaran PAI Di Pondok Pesantren Kreatif Agro Nuur El-Falah Salatiga." Nazhruna: Jurnal Pendidikan Islam 2, no. 2 (26 Agustus 2019): 290-309. https://doi.org/10.31538/nzh.v2i2.331.

Hasan, Moch Sya'roni, dan Nikmawati Nikmawati. "Model Pembelajaran Pai Dalam Membentuk Kepribadian Islami Siswa Di Smk Dr Wahidin Sawahan Nganjuk." TA'LIM: Jurnal Studi Pendidikan Islam 3, no. 1 (7 Januari 2020): 1-21. http://www.e-jurnal.unisda.ac.id/index.php/talim/article/view/1751.

Hofman, Roelande H., Jan de Boom, Marieke Meeuwisse, dan W. H. Adriaan Hofman. "Educational Innovation, Quality, and Effects An Exploration of Innovations and Their Effects in Secondary Education." Educational Policy 27, no. 6 (1 November 2013): 843-66. https:// doi.org/10.1177/0895904811429288.

Huda, Syamsul, Muhammad Syahrul, Mu'min Firmansyah, Rahmi Ramadhani, dan Andika Eko Prasetiyo. “The Relationship between Problem-Solving Ability and Students' Characters Based on Islamic Perspectives." Tadris: Jurnal Keguruan Dan Ilmu Tarbiyah 4, no. 2 (27 Desember 2019): 203-14. 
Diana Susilawati Sj, Muhammad Anas Ma`arif, Afif Zamroni

https://doi.org/10.24042/tadris.v4i2.5299.

Krisbiyanto, Achmad. “Efektifitas Kepemimpinan Kepala Madrasah Terhadap Mutu Pendidikan MTsN 2 Mojokerto." Nidhomul Haq: Jurnal Manajemen Pendidikan Islam 4, no. 1 (10 Maret 2019): 52-69. https:/ / doi.org/10.31538/ndh.v4i1.182.

Ma`arif, Muhammad Anas, dan Ibnu Rusydi. "IMPLEMENTASI PENDIDIKAN HOLISTIK DI PONDOK PESANTREN AMANATUL UMMAH MOJOKERTO." EDUKASI: Jurnal Penelitian Pendidikan Agama Dan Keagamaan 18, no. 1 (27 April 2020). https:// doi.org/10.32729/edukasi.v18i1.598.

Ma'arif, Muhammad Anas. “Analisis Konsep Kompetensi Kepribadian Guru PAI Menurut Az-Zarnuji." ISTAWA 2, no. 2 (2017): 35-60. http://journal.umpo.ac.id/index.php/istawa/article/view/624.

Masaong, Abd Kadim. Supervisi pembelajaran dan pengembangan kapasitas guru. Bandung: Alfabeta, 2013.

Muhaimin. Pengembangan Kurikulum Pendidikan Agama Islam. Cet. 5. Jakarta: Raja Grafindo Persada, 2012.

Pratama, Yoga Anjas. “Implementasi Manajemen Pembelajaran Karakter Berbasis Total Quality Management Di SMP Muhammadiyah 3 Yogyakarta." Nidhomul Haq: Jurnal Manajemen Pendidikan Islam 4, no. 1 (7 Maret 2019): 1-22. https://doi.org/10.31538/ndh.v4i1.184.

Saada, Najwan, dan Haneen Magadlah. "The meanings and possible implications of critical Islamic religious education." British Journal of Religious Education 0, no. 0 (25 Juni 2020): 1-12. https:// doi.org/10.1080/01416200.2020.1785844.

Surya, Mohammad. Psikologi Guru, Konsep dan Aplikasi, dari Guru untuk Guru,. Bandung: Alfabeta, 2013.

Syafe'i, Imam. “Tujuan Pendidikan Islam." Al-Tadzkiyyah: Jurnal Pendidikan Islam 6, no. 2 (2015): 151-66.

Syamsudin, Syamsudin, Muhammad Hidayat Ginanjar, dan Moch Yasyakur. "Evaluasi Mutu Pembelajaran Pendidikan Agama Islam (pai) Di Smp Pembangunan Satu (pesat) Kota Bogor Tahun Ajaran 2017/2018." Prosa PAI : Prosiding Al Hidayah Pendidikan Agama Islam 1, no. 2B (3 Juli 2019): 167-78. https://doi.org/10.30868/ppai.v1i2B.468.

Yin, Robert K. Case Study Research: Design and Methods, 2013. 
Manajemen Program Pengembangan Kurikulum,...

Young, Steve. "Islamic Education and the Public Sphere: Today's Pesantren in Indonesia - By Florian Pohl." Teaching Theology E Religion 14, no. 3 (2011): 28889. https://doi.org/10.1111/j.1467-9647.2011.00723.x.

Zakiah, Daradjat. Dasar-dasar agama Islam: buku daras pendidikan agama Islam pada perguruan tinggi umum. Jakarta: Bulan Bintang, 1992. 